\title{
The Impact of Economic Activities on Deforestation in Bauchi State. (A Theoretical perspective.)
}

\author{
Mohammed Uwaisu Hussaini \\ Department of General Studies, Federal Polytechnic, Bauchi.
}

\begin{abstract}
For thousand of years the action of man has been gradually diminishing the world's forest resources by clearing and felling of trees for fuel, bush burning or making way for agriculture, settlement and industry. This was a relatively slow process in many areas in the past, but it has now been speeded up by population explosion as well as economic activities especially in the provision of fuel wood. The Food and Agriculture Organization (FAO) defines deforestation as a reduction of forest stand density to less than 20 percent of its original cover. Ayuba (2005) defined deforestation as the indiscriminate felling of trees with little or no effort at replacement. Economic activities if pursued without environmental considerations will in the long run limit the scope for growth and overall economic development, more so when the resources derivable from it are economic necessities (Oyeranti, 1998). Therefore the objective of this paper is to identify those economic activities that aid deforestation in Bauchi State with a view to proffer solution to this environmental problem. With the aid of various literatures and discussions from experts in the field, the study will identify the economic activities that contribute to deforestation in Bauchi State. The study among other things identified that demand for fuel wood, intensive use of land for food production and grazing, unemployment, urbanization, migration are some of the activities responsible. The study therefore suggest that tree planting campaign should vigorously pursued, stringent laws to be put in place against indiscriminate cutting down of trees, make alternative source of fuel wood such as kerosene cheaper or encourage the use of efficient wood stove and sensitization campaign to educate the general public on the dangers of deforestation.
\end{abstract}

Key wood: Deforestation, economic activities

\section{Introduction.}

For thousand of years the action of man has been gradually diminishing the world's forest resources by clearing and felling of trees for fuel, bush burning or making way for agriculture, settlement and industry. This was a relatively slow process in many areas in the past, but it has now been speeded up by population explosion as well as economic activities especially in the provision of fuel wood. In many countries of the world, wood is the main source of fuel, additional land is constantly being developed for agriculture. The forest vegetation is still being rapidly reduced.

The seriousness of this development is now being realized by an increasing number of people and national institutions such as Federal Environmental Protection Agency (FEPA), as well as international bodies like the Food and Agricultural Organization (FAO). The United Nations Conference on Environment and Development (UNCED) considered environmental protection to be an integral part of development which is aimed at poverty alleviation and striking a balance between economic efficiency and sustainability. Therefore urgent measures are required to arrest the situation before it is too late. As one of the prerequisites for the attainment of economic growth and development in any country, is a sound and sustainable environment, environmental economists worldwide are becoming increasingly aware of the importance of environmental issues for the success of economic growth. Equally economists have always something to say about the relationship between economic welfare and the stock of natural resources. The world economy is inextricably linked to the environment since societies have to extract, process, and consume natural resources. The economy makes a noticeable impact on the environment and environmental quality, which in turn affects the performance of the economy (Oyeranti, 1998). Economic activities if pursued without environmental considerations will in the long run limit the scope for growth and overall economic development, more so when the resources derivable from it are economic necessities.

The quest for sustainable development has in recent years become a key concern for the developing regions of the world. Issues pertaining to the ecosystem's capacity to tolerate and respond to increasing demand for environmental resources followed by other human-induced activities, all these are serious issues for sustainable management of forest resources. Finding and disseminating solutions to these problems have been undertaken in many research works such as Mortimer (1989), Sanda et al (1991), Olofin (1993), Oyeranti (1998), Hamidu (1999), Kadandani (2002), Adeokun et al (2002), Ladipo et al (2002), Maigari (2002) and 
Ayuba (2005). This paper is different as it intends to highlights' the likely economic activities that promote deforestation and at the same time intend in finding a lasting solution to deforestation.

The Food and Agriculture Organization (FAO) defines deforestation as a reduction of forest stand density to less than 20 percent of its original cover. Ayuba (2005) defined deforestation as the indiscriminate felling of trees with little or no effort at replacement. Maigari (2002) added that is when the replacement results into ecological imbalance or degradation that you refer to it as deforestation. This is apparent, because of the fundamental roles of vegetation to ecosystem including man. NORAD (1994) explained that clear-cutting in natural forests is often associated with deforestation or destruction of forest.

In the course of this paper secondary data will be used. The secondary data will be source mostly from available literatures such as environmental journals, government publications and the Internet.

\section{Objectives of the paper.}

The primary aim is to identify the economic activities that determine deforestation in Bauchi State with a view to proffer solution to this endemic environmental problem.

\section{The Economy of the selected Area.}

Agriculture is by far and for long has been the backbone of the economy of Bauchi State and the greatest employer of labour, with about 80 percent of the population of the state engaged in farming and livestock husbandry (Ajaegbu, 2000). This explains the vast expansible arable and Fadama land, coupled with the absence of alternative means of livelihood makes it possible for about $75-80 \%$ of its inhabitants to engage in farming and rearing of livestock. The major crops produced in the State include cotton, maize, groundnuts, millet, guinea corn and rice and substantial population also exists of cattle herdsmen because of the large expanse of land the animals are mostly cattle, sheep and goat.

Despite the vast land available, output has not reached the desired level largely as a result of the type of farming practice such as land tenure system, population, lack of agricultural inputs, and low level of farm produce prices. Aggravating the situation is the lack of finance, fertilizer, improved variety of seeds and seedlings, pesticides and herbicides. The Bauchi State Agricultural Supply Company (BASAC) which is the supporting agency for the supply of good quality seedlings and pesticides and the Bauchi Fertilizer Company both have remained comatose for many years largely due to mismanagement.

\section{Economic Activities that Promotes Deforestation in the Area.}

Nigerian environmental group have alerted the government that massive deforestation of the nations severely deflated forest will continue as those who can no longer afford gas and kerosene would resort to felling of more trees to get fuel wood due to the high prices of the alternative products (Environment News Service, 2006). In addition to that Obueh (2000) disclosed that firewood demand (The principal cause of deforestation) in the Northern Nigeria is expected to rise to 83.5 million cubic meters by 2010. Generally in Nigeria and Bauchi State in particular, firewood, kerosene and electric/gas cooker are the major cooking tools. Majority of the people rely on fuel wood and kerosene stove for domestic cooking while only a few use gas and electric cookers. Continues increases in the prices of kerosene from a mere N24 per litre in 1999 to N78 per litre in 2003 (Mobil, Annual report of 1999, 2003) in addition to the unreliable nature of electricity have forced both rural and urban dwellers to abandon kerosene stoves and electric cookers in favour of the comparatively cheaper fuel wood, which is seen as a reliable substitute. In some areas, the forests have been destroyed or have receded so that the time and effort required for collection and preparation of wood for domestic use has become excessive. The extensive use of wood as energy source in developing countries has led to increase deforestation with attendant environmental problems such as erosion, silting of streams, increase in flood and possible climate change.

Bauchi State with an estimated population of 4.2 million people and a growth rate of $3.0 \%$, with economic active population constituting $41.2 \%, 84 \%$ of the population live in the rural areas, $75-80 \%$ of the inhabitants engage in farming. As population increases, the amount of forest land usually declines, because demand for land for food production and other uses intensifies. When land is intensively cropped, the natural tree cover and soil fertility may be loss which will lead to changes in the quality and quantity of the vegetation \{Bauchi State Economic Empowerment and Development Strategy (BASEED), 2005\}. Intensive and extensive agricultural practices have reduced the natural vegetation and undisturbed forest of the state to less than $1 \%$ of the total land area of $66,000 \mathrm{~km}^{2}$, between $1976 / 78$ and 1993/95, intensive agriculture increased from 20,026 $\mathrm{km}^{2}$ to $27,338 \mathrm{~km}^{2}$, extensive agriculture rose from $16.7 \%$ to $18.3 \%$ and woodland decline from $14,754 \mathrm{~km}^{2}$ to $3,571 \mathrm{~km}^{2}$ (FORMECU, 1998). Population pressure has accelerated the rate of deforestation through the search for cultivable land for farming and grazing. It is occurring at an unprecedented rate and is creating local and in all probability global environmental problem such as global warming. The effect of this intense demand results 
in a decline of vegetation cover and impoverishment of the soil and a general deterioration of environment condition.

Mortimor (1989) argued that in the absence of job opportunities, the rural populace would be forced to engage in the sale of wood as a useful source of income. In developed countries, environmental degradation is primarily the product of wealth, while for developing countries it is primarily a product of poverty. Job creation in Bauchi State is highly government dependent, employment opportunities are therefore static and new ones are not generated, with a total work force of just 20,989 in 2006 constituting an in significant percentage of the population. Of the 4.2 million people who live in the state, 2 million people still live under N50 per day, thus poverty is at a very unacceptable level (BASEED, 2005). Deforestation has contributed its own share in producing a drier climate, which threatens human existence by impacting on the general ecological setting of our environment.

Also the creation of additional Local Government led to rapid rate of urbanization, in an effort to provide infrastructural facilities in these newly established headquarters additional forestlands have to be cleared \{National Action Programme (NAP), 2000\}. In Bauchi State four new Local Government Areas were created, secretariat, houses, roads, hospital, schools and many more were constructed all these have further effect on the quantity and quality of the available forested land. The Plateau crisis of 2001 led to migration of a lot of people to Bauchi State, most of them farmers and wood sellers. The people settled mostly in the conserved forested areas and have since severely exploited the conserved forest of the Toro and Tafawa Balewa Local Government Areas of the State either for farming, grazing or wood stocking \{Ministry of Agriculture and Natural Resource (MANR) Bauchi State, 2003\}. The catastrophic impact is seen in accelerating soil erosion which results in permanent loss in agricultural productivity, in advancing desertification accompanied by drought and famine, in declining coastal and inland fisheries with the associated threats to food security, in the misuse of agrochemicals that poison both people and the environment, in the alarming sedimentation of fragile coral reefs; and in the destruction of biodiversity-rich wetlands.

The dry land of Nigeria, including the vast lands of Bauchi State is said to support much of the country's livestock economy. Additional pressure is also put on pasture resources by livestock from neighboring countries of Chad, Niger and Cameroun. The Northeast corridor, emanating from Niger/Chad Republic and running through Borno, Yobe, Kano, Jigawa, Bauchi, Adamawa, Gombe and Plateau States terminating at Benue/Niger river basins supplies the needed pasture. This corridor carries millions of cattle annually in search of suitable pastures. Livestock population in Nigeria has been estimated to consist of 16 million cattle, about 13.5 million sheep, some 26 million goats, approximately 2.2 and 150 million pigs and poultry respectively. Evidence from a study conducted showed that the average livestock population density to be 12.33 per hectares, well above the carrying capacity. Overgrazing resulting from overstocking cannot be completely ruled out as a major cause of deforestation (NAP, 2000).

The deforestation of the Bauchi State forest reserves has obviously defied the over 50years control efforts of various governmental and non-governmental organization. Right from colonial era to the present day, control and preventive measures such as tree planting campaign in the form of afforestation projects, the acquisition, custody and expansion of gazetted forest, provision of shelter belt and woodlot all were carried out, but the problem has continued to progress. This can be due to the style undertaken in the implementation of these programmes, which has largely been inconsistent, uncoordinated, and piecemeal and consists of single set of remedial and ad hoc measures. The end result is the increasing vulnerability of the people to the hazard of deforestation (Musa, 2001).

\section{Conclusion}

As the ultimate support of much economic activity, the environmental resource base makes a critical contribution to the cause of sustainable development. Especially in developing countries like Nigeria, environmental resources are increasingly being depleted. Degradation and destruction of environmental systems and natural resources are now assuming massive proportions and a threat to continued sustainable development. It is now generally recognized that economic development can be an important contributing factor to growing environmental problems in the absence of appropriate safeguards.

A greatly improved understanding of the natural resource base and environmental systems that support national economies is needed if patterns of development that are sustainable can be determined and recommended to government. Therefore there is an urgent need for policy makers to be supplied with an additional framework to deal with issues of environmental degradation such as deforestation, so that they can evaluate the issues for the most efficient points of policy interventions. 


\section{Recommendation}

Tree planting campaign should continue to be encouraged and possibly incorporate it into school curriculum. In addition support a healthy competition among the various communities in the promotion of tree planting campaign. Stringent laws that have strong punitive punishment should be introduce to deal with erring members of the community. Government should come up with a policy that will discourage the use of fuel wood especially in terms of reducing the price of kerosene or encourage the mass production of cheaper fuel wood efficient stove. Lastly authorities should embark of sensitization campaign to educate the masses on the serious effects of deforestation to the various communities.

\section{Reference:}

[1] Adeokun et al (2002). Assessment of Exploitation of Non-Timber Forest Products in Omo Forest Reserve, Ogun State. A paper delivered at FAN $28^{\text {th }}$ Annual Conference, held in Akure, Ondo State Nigeria from $4^{\text {th }}-8^{\text {th }}$ November 2002.

[2] Allen, J. and Barnes, D. F. (1985). "The causes of Deforestation in Developing Countries", Annals of the Association of American Geographers, vol. 75 (2) pp 163-184.

[3] Arrow, K. J. and Fisher, A. (1974). "Preservation, Uncertainty and Irreversibility", A Quarterly Journal of Economics, Vol. 87, pp 312-319.

[4] Ayuba, H. K. (2005). Environmental Science: An Introductory Text. Apani Publishers, Kaduna-Nigeria.

[5] Bar bier, E. and Burgess, C. J. (1996). "Economic Analysis of Deforestation in Mexico", Environment and Development Economics (1) pp 203-239.

[6] Burgess, J. C. (1993). “Timber Production, Timber Trade and Tropical Deforestation”, AMBIO, Vol. 22 (2-3), pp 136-143.

[7] Bauchi State Economic Empowerment and Development Strategy (BASEED), (2005). Report on Bauchi State Economy. http://www.bauchi-state-nigeria.info/baseeds/report.pdf.

[8] Bauchi State Environmental Protection Agency (BASEPA), (2000). Annual Yearly Report. Bauchi State Govt. publication, (2005).

[9] Chida Forestry Advisers Network, (2003). DEFORESTATION: Tropical Forests in Decline. info@ rcfa-cfan.org

[10] Capistrano, A. D. and Kiker, C. F. (1995). "Macro-Scale Economic Influences on Tropical Forest Depletion". Ecological Economics Vol. 52, No 3, pp 309-328.

[11] Capistrano, A. D. (1994). "Tropical Forest Depletion and the Changing Macro-economy". Brown and Pearce (ed) The Causes of Tropical Deforestation. University College London Press.

[12] Cleaver, M. K. and Schreider, A. G. (1994). "Reversing The Spiral: The Population, Agriculture and Environment Nexus in SubSaharan Africa". The World Bank, Washington D.C.

[13] Deacon, P. J., and M. B. K. Darkoh. 1987. The policies and practices behind the degradation of Kenya's land resources: Preliminary review. Journal of Eastern African Research and Development 17: 34-51.

[14] Greenstone Software- Standard Version, World Environmental Library Version 1.1. Environment News Service, (2006). news@ens-news.com

[15] FAO, (1984). Monitoring and evaluation of participatory forestry projects. Pub. Policy and Planning Service FAO Forestry Department Rome, 1985. P. 1-4 (133p).

[16] FAO, (1998). Reading in sustainable forest management. For Pap. 122 FAO, Rome.

[17] FORMECU, (1998). The Assessment of Vegetation and Land Use Changes in Nigeria between 1976/78 and 1993/95. Report prepared by Geomatics International Inc., under the World Bank Funded Environmental Management Project (EMP).

[18] FORMECU, (2001). Micro-Watershed and Environmental Management Programme: Environmental Assessment Draft Report for Bauchi State. A World Bank-funded Project for the Forestry Management, Evaluation and Coordinating Unit, Abuja, Nigeria, prepared by Geomatics Nigeria Limited.

[19] Koohafkan, A.P. (1996). Desertification, Drought and Consequences. Sustainable Development Department, Food and Agricultural Organisation (FAO).

[20] Hamidu, M.(1999). Analysis of the Economic Resource of Small-Scale Farms in Dass, Bauchi State. Unpublished Msc thesis presented to Abubakar Tafawa Balewa University, Bauchi.

[21] Kadandani, B. I. (2002). Socio-Economic Determinant of Deforestation in Katsina State Nigeria. Unpublished PhD research work submitted to Economics Department Bayero University, Kano.

[22] Ladipo, O.O. et al (2002). Domestic Energy and Conservation needs for indigenous Forest Species in Nigeria. A paper delivered at FAN $28^{\text {th }}$ Annual Conference, held in Akure, Ondo State Nigeria from $4^{\text {th }}-8^{\text {th }}$ November 2002.

[23] Mabogunje, L. A. (1996). "Environmental Challenges of the Sub-Saharan Africa". Centre for Advanced Social Science (CASS) Monograph No 7 Lagos.

[24] Maigari, A. I. (2002). Introduction to Environmental Problems and Management. Wa'adallah Environmental Consult, Kano Nigeria.

[25] Ministry of Agriculture and Natural Resource (MANR), (2003). Position paper on the state of Forest Reserve in Bauchi State. A communiqué by Forestry Officers of the Forestry Unit MANR, Bauchi State 2004.

[26] Mortimor, M. J. (1989). Adapting to Drought; Farmers, Famine and Desertification in W/Africa. Cambridge Press, UK

[27] Musa, M. I. (2001). Environmental Management and Challenges in Bauchi State. A lecture organized by Bauchi State Ministry of Lands, Housing and Environment, held at Bauchi from $13^{\text {th }}-14^{\text {th }}$ February 2001.

[28] National Action Programme (NAP), (2000). National Action Programme to Combat Desertification and Mitigate the Effect of Drought. Federal Environmental Protection Agency (FEPA) paper towards the implementation of the United Nations Convention to Combat Desertification.

[29] Olofin, E.A. (1993). Strategies of Combating Desertification in Nigeria: Lecture Delivered at Workshop of Drought, Deforestation and Desertification, Bayero University Kano, Nigeria $20^{\text {th }}$ to 23rd January 1993.

[30] Oyeranti, O.A. (1998). Environmental Degradation and Economy wide Policies: A computable General Equilibrium modeling of Deforestation in Nigeria. Unpublished PhD proposal presented to the Dept, of Economics University of Ibadan.

[31] Okali, D. U. U. (1985). The Nigerian Environmental; Ecological Limits of Abuse. Keynotes paper in the Nigerian Environment; Ecological Limits of Abuse. Proceeding of Annual Conference and General Meeting of the Lyonia, Ecological Society of Nigeria (ECOSON) Held at the River state University of Science \& Technology, Port Harcourt, 3rd -5th May, 1985. 
[32] Palo, M., Mery, G. and Salmi, J. (1987). "Deforestation in the Tropics: Pilot Scenarios Based on Quantitative Analysis" in Deforestation or Development in the Third World, Palo and Salmi (eds). Division of Social and Economic Forestry, Finnish Forest Research Institute.

[33] Pachauri, R. K. and Kanetkar, R. S. (1997). Environment, Energy, and Economy: Strategies for Sustainability (UNU, 1997, 381pages).

[34] Peace Corps, (1995). Peace Corps, Information Collection and Exchange, 806 Connecticut Avenue, N.W., Washington, D.C. 20525, U.S.A.

[35] Sanda, et al (1991). Firewood Consumption Pattern in Sokoto State. Unpublished Seminar paper presented to Usman Danfodio University, Sokoto.

[36] Sharma, P. N., Rietberg, S., Heimo, C. R. and Patel, J. (1994). " A Strategy for the Forest Sector in Sub-Saharan Africa”, The World Bank Technical Paper Number 25, The World Bank.

[37] Southgate, D., Sierra, R. and Brown, C. (1991). "The Causes of Tropical Deforestation in Ecuodor: A Statistical Analysis" World Development, Vol. 19 pp 1145-1151.

[38] UNDP/World Bank, (1992). African Development Indicators, New York and Washington D.C

[39] Unemo, L. (1993). "Environmental Impact of Government Policies and External Shocks in Botswana: A CGE Model Approach" Beijer Discussion Paper Series No. 26.

[40] Todaro, M. P. and Smith, S. C., (2004). Economic Development. Pearson Education $8^{\text {th }}$ edition.

[41] Tolba, M.K. (1986). Desertification. WAID Bulletin, 35; 17- 22. 